\title{
Study on Prevalence and Resistance Patterns of Bacterial Pathogens Isolated from Canine Pyoderma
}

\author{
Alok Kumar Chaudhary ${ }^{1}$, Ashok Kumar ${ }^{2}$ and Mukesh Shrivastva ${ }^{1}$ \\ ${ }^{1}$ Department of Veterinary Medicine, DUVASU Mathura, India \\ ${ }^{2}$ Division of Animal Health, C.I.R.G., Makhdoom, Farah Mathura, Pandit Deen Dayal \\ Upadhyaya Pashu Chiitsa Vigyan Vishwavidyalaya evam Gau Anusandhan Sansthan, \\ Mathura- 281001 (DUVASU), India
}

*Corresponding author

\begin{tabular}{|c|c|}
\hline & A B S T R A C T \\
\hline $\begin{array}{l}\text { Prevalence and } \\
\text { Resistance patterns, } \\
\text { Bacterial pathogens }\end{array}$ & \multirow{3}{*}{$\begin{array}{l}\text { Out of } 120 \text { samples, } 65 \text { skin swab samples obtained with suspected Pyoderma infection } \\
\text { cases were subjected for triple bacterial cultured and isolation. Predominant bacterial } \\
\text { isolates culture were Staphylococcus spp. }(92.30 \%) \text {, while others reported as E. coli spp. } \\
\text { (10.76\%), Pseudomonas spp. (10.76\%), Proteus spp. (9.23\%), Klebsiella spp (4.61\%), } \\
\text { Streptococcus spp. ( } 9.23 \%) \text { were also isolated meagerly. Only Different isolated strains of } \\
\text { Staphylococcus interradius groups. were included for in- vitro antibiotic culture and } \\
\text { sensitivity test against routinely used systemic antibiotics and evaluate the resistance } \\
\text { patterns of isolated of Staph.intermidius groups bacterial strains resulted in all the strain } \\
\text { showed 100\% resistance against oxytetracycline while Amoxicillin-clavulanic acid, } \\
\text { Cephalexin, Rifampicin, Doxycycline and Enrofloxacin were showed at different levels of } \\
\text { susceptibility. }\end{array}$} \\
\hline Article Info & \\
\hline $\begin{array}{l}\text { Accepted: } \\
\text { 15 December } 2018 \\
\text { Available Online: } \\
10 \text { January } 2019\end{array}$ & \\
\hline
\end{tabular}

\section{Introduction}

Canine Pyoderma is one of the multifactorial bacterial skin diseases in worlds wide, clinically characterized with primary skin lesions included papules, pustules, followed by secondary skin lesions crusting, epidermal collarettes, alopecia, scaling, erythema, pruritus, lichenification and hyperpigmentation(Manon etal.,1990).The primary pathogens of Pyoderma is Staphylococcus intermedius (Scott et al., 1998), along with Staphylococcus aureus (Paradis et al., 2001). However, other causative organisms such as Proteus spp., Pseudomonas spp., E. coli, Actinomyces spp.,
Actinobacillus spp., Fusobacterium spp., and Mycobacterium spp. can also occur in deep pyoderma (Paradis et al., 2001). They are mostly harmless commensalism of the skin and mucous membranes but are potentially pathogenic to humans and many other animal species (Vanni et al., 2009). Deep skin infections are generally the continuation of a superficial infection (Papich et al., 1995). Currently, the diagnosis of canine Pyoderma is based on history and clinical observation of compatible clinical signs. Usually three complementary aids used to confirm the clinical diagnosis of Pyoderma includes cytology, skin scraping, and isolation and culture of bacterial and fungal however the 
examination of ectoparasite infestation. The antibiotic resistance epidemic and this has increased in developing countries since the use of antibiotics to treat people and animals is not regulated (Hart and Kariuki, 1998) Keeping in view the importance of skin diseases in pets and their zoonotic effect in human, the study was planned to determine the antibiotic resistance pattern and prevalence of bacterial pathogen strains from canine Pyoderma.

\section{Materials and Methods}

The studied were carried out of 120 samples, 65 skin swab samples with suspected Pyoderma infection cases with different age breeds and sex during the period of 2010 to 2011 on outpatient of the TVCC hospital affiliated to DUVASU University. Detailed clinical examinations were done as per standard. Routine hematological parameters were estimated pre and post treatment as per the method of Jain (1986). Multiple deep skin scraping form at least three sites of the affected area of suspected cases collected as per method suggested by (Higgins, 1984). Microorganism identification was accomplished according to the staining, cultural morphological, and pure cultures of Staphylococcus were used for identification and differentiation of genus Staphylococcus by KB004 HiStaph ${ }^{\mathrm{TM}}$ Identification kit (as per method described by HiMedia Mumbai, India). KB004 is a standardized, colorimetric identification system utilizing twelve conventional biochemical tests. The tests are based on the principle of $\mathrm{pH}$ change and substrate utilization. On incubation, organisms undergo metabolic changes which are indicated as a colour change in the media that is either visible spontaneously or after addition of a reagent.

The analysis of the resistance pattern was carried out using the Bauer-Kirby disk diffusion technique (Bauer and Kirby, 1966). In vitro-drug sensitivity test of 60 isolates (180triplets) Staphylococcus strain against the following antibiotics disc was included (HiMedia, Mumbai) viz., Ampicillin-Clavulanic acid (AMC-30mcg), Enrofloxacin (EX-10 mcg), Cephalexin (CPH-mcg) Doxycycline. (DO-30mcg) Rifampicin, (RIF-30mcg) and Oxytetracycline (Otc-30mcg) (NCCLS, 2000) to determine the resistance patterns of bacterial pathogens isolated from canine pyoderma. Statistical analysis of data pertaining to different parameters was done as per standard methods (Snedecor and Cochran, 1969).

\section{Results and Discussion}

During the one year study period, a total 282 dermatological disorders cases were recorded out of these 120 dogs with heterogeneous population of different age, sex, and breeds were included for detailed bacteriological studied . Out of 120 skin samples of dogs, 65 samples were positive for pathogenic bacteria and 29 samples were positive for fungal growth on Saboraud's dextrose agar media and further confirmation by cotton blue staining and examined under light Microscope while 26 samples were negative or nonpathogenic organisms. In the bacterial culture and morphological studied of out 65 samples showed the highest percentage $92.30 \%$ (58) positivity for Staphylococcus spp., while other bacteria's also find with or without Staphylococcus spp. like E. coli spp.; Pseudomonas spp. Proteus spp.; Klebsiella spp.; Streptococcus spp.; Gram -ve coccobacillus spp. (Hillier et al., 2006); showed their distribution in affected population as shown in Table 1 (Fig. 1-3).

The Staphylococcus spp. 58 (92.30\%) showed positive predominant frequency rate on bacterial culture and isolation as shown on table 1, Similar result was also found by Mark 
et al., (2003) with 90\% similar prevalence with or without other bacteria's isolated Patil et al., (1999) also agreement with $82 \%$ and Scott et al., (1995) were also reported similar causative agent of canine Pyoderma.

The biochemical analysis for species identification (staphylococcus species by using KB004 HiStaph ${ }^{\mathrm{Tm}}$ Identification Kit which is based on the principle of $\mathrm{pH}$ change and substrate utilization and metabolized on incubation, and results the percentage of positive isolates was summarized in table 2 .

Out of 60 positive pure samples of Staphylococcus spp. biochemically identified as $52(87 \%)$ of isolates predominantly shown a positive result for $S$. intermedius and followed S. aureus subsp.aureus spp. 5 (8\%), S. epidermidis spp. $2(3 \%)$ and S. schleiferi subsp. coagulans $1(2 \%)$. the various author was reported similarly isolated Staphylococcus intermedius strain positive (Frank, 2002 and Hoekstra et al., 2002; Scott et al., 1998). The distribution pattern these isolates also recorded and result shown in table 3. Staphylococcus intermedius spp., as mass etiological agent various author, was isolated by Hill and Morales (1994), Scott et al., (1994), Ihrik (1996), Scott et al., (1998) and May et al., (2005) reported the isolation of cases of Staph schleiferi sub spp. coagulans; Medleau et al., 1986 also identified as Staph. intermedius, S. aureus, and S. epidermidis (Fig. 4 and 5).

Table.1 Prevalence of different bacterial isolated from canine Pyoderma

\begin{tabular}{|c|l|c|c|}
\hline SN & Isolated bacteria & Total no of isolates & Percentage \\
\hline $\mathbf{1}$ & Staphylococcus spp. & 60 & 92.30 \\
\hline $\mathbf{2}$ & E. coli spp. & 7 & 10.76 \\
\hline $\mathbf{3}$ & Pseudomonas spp. & 7 & 10.76 \\
\hline $\mathbf{4}$ & Proteus spp. & 6 & 9.23 \\
\hline $\mathbf{5}$ & Klebsella spp. & 3 & 4.61 \\
\hline $\mathbf{6}$ & Streptococcus spp. & 6 & 9.23 \\
\hline $\mathbf{7}$ & Gram -ve coccobacilus spp & 2 & 3.07 \\
\hline
\end{tabular}

Table.2 Identification index of various Staphylococcus species bacteria recovered from Pyoderma

\begin{tabular}{|c|c|c|c|c|c|c|c|c|c|c|c|c|c|c|c|}
\hline \multirow{2}{*}{$\begin{array}{l}\text { Sl. } \\
\text { No }\end{array}$} & \multirow{2}{*}{$\begin{array}{c}\text { Species of } \\
\text { Staphylococcus }\end{array}$} & \multicolumn{12}{|c|}{ Biochemical kit analysis } & \multirow{2}{*}{$\begin{array}{l}\text { No of }(+v e) \\
\text { isolates }\end{array}$} & \multirow{2}{*}{$\begin{array}{c}\text { Per } \\
\text { centage }\end{array}$} \\
\hline & & VP & $\mathrm{AL}$ & $\mathrm{ON}$ & Ur & $\mathrm{Au}$ & $\mathrm{Mn}$ & $\mathrm{Su}$ & Lac & Ar & $\mathrm{Ra}$ & $\operatorname{Tr}$ & Ma & & \\
\hline 1. & S. intermedius & - & + & - & + & - & & + & - & - & - & + & + & 52 & 87 \\
\hline 2. & $\begin{array}{l}\text { S.aureus } \\
\text { subsp.aureus }\end{array}$ & + & + & - & + & + & + & + & + & - & - & + & + & 5 & 8 \\
\hline 3. & S.epidermidis & + & + & - & + & + & - & + & - & - & - & - & + & 2 & 3 \\
\hline 4. & $\begin{array}{l}\text { S.schleiferi sub } \\
\text { spp.coagulans }\end{array}$ & + & + & $\mathrm{N}$ & + & + & - & - & - & - & - & - & - & 1 & 2 \\
\hline
\end{tabular}

$\mathrm{VP}=$ Voges Porskaur, $\mathrm{AL}=$ Alkaline phosphatase, $\mathrm{ON}=\mathrm{ONPG}, \mathrm{Ur}=$ Urease, $\mathrm{Au}=$ Arginine utilization, $\mathrm{Mn}=\mathrm{Mannitol}, \mathrm{Su}=$ Sucrose, $\mathrm{Lac}=$ Lactose, $\mathrm{Ar}=$ Arbinose, $\mathrm{Ra}=$ Raffinose, $\mathrm{TR}=$ Trehalose, $\mathrm{Ma}=$ Maltose 
Table.3 Infection status of bacterial isolates with different Staphylococcus spp. reported in pyoderma from 65 samples

\begin{tabular}{|c|l|c|c|}
\hline SN & Isolates organism & Total no of isolates & Percentage \\
\hline $\mathbf{1}$ & Staphylococcus intermedius & 28 & 43.13 \\
\hline $\mathbf{2}$ & S. intermedius + E.coli & 4 & 6.15 \\
\hline $\mathbf{3}$ & S. intermedius + Streptococcus spp & 3 & 4.61 \\
\hline $\mathbf{4}$ & Streptococcus spp + E. coli & 3 & 4.61 \\
\hline $\mathbf{5}$ & Pseudomonas spp. + S. intermedius & 5 & 7.69 \\
\hline $\mathbf{6}$ & Proteus spp. + S. intermedius & 4 & 6.15 \\
\hline $\mathbf{7}$ & Klebsella spp. + Staph. intermedius & 3 & 4.61 \\
\hline $\mathbf{8}$ & Proteus spp + pseudomonas spp & 2 & 3.07 \\
\hline $\mathbf{9}$ & Staph. epidermidis + Gram -ve coccobacilus & 2 & 1.53 \\
\hline $\mathbf{1 0}$ & S. intermedius + S.aureus & 5 & 7.69 \\
\hline $\mathbf{1 1}$ & S. schleiferi sub spp. coagulans, & 1 & 1.53 \\
\hline $\mathbf{1 2}$ & Other non-pathogenic microorganism & 5 & 7.69 \\
\hline & Total & 65 & $100 \%$ \\
\hline
\end{tabular}

Table.4 Infection percentage of isolated bacteria from canine pyoderma

\begin{tabular}{|c|c|c|c|c|c|c|c|c|}
\hline \multirow[t]{2}{*}{ S.N. } & \multirow[t]{2}{*}{ Isolates organism } & \multicolumn{6}{|c|}{ Number of resistance organism } & \multirow{2}{*}{$\begin{array}{c}\text { samples } \\
\text { tested }\end{array}$} \\
\hline & & $A C$ & $C L$ & $\boldsymbol{R F}$ & $T I$ & DO & $E X$ & \\
\hline 1 & Staph. intermedius & 0 & 2 & 3 & 52 & 7 & 8 & 52 \\
\hline 2 & S. aureus subsp. aureus & 0 & 1 & 1 & 5 & 2 & 1 & 5 \\
\hline 3 & S.epidermidis & 1 & 1 & 0 & 2 & 1 & 1 & 2 \\
\hline 4 & S.schleiferi sub spp. coagulans & 0 & 0 & 0 & 1 & 0 & 0 & 1 \\
\hline
\end{tabular}

Fig.1 Golden yellow colony of Staphylococcus spp. growth on N.A, Fig.2 Metallic seen E. coli growth on E.M.B, Fig.3 Green colony of Pseudomonas spp. growth on N.A

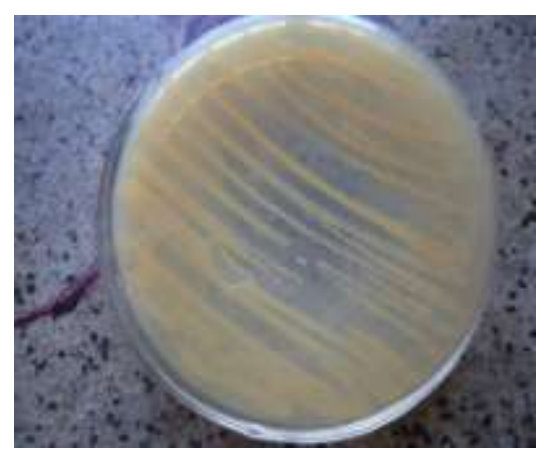

Fig.1

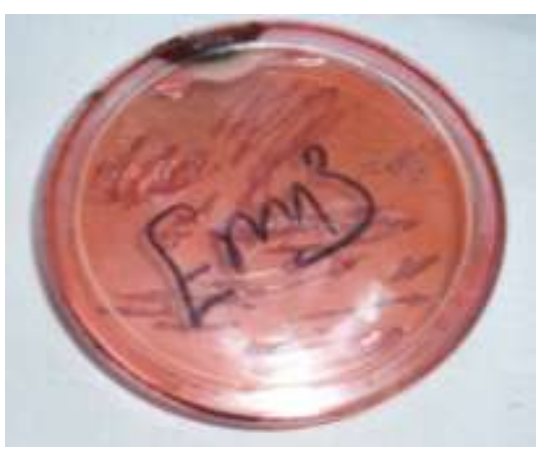

Fig.2

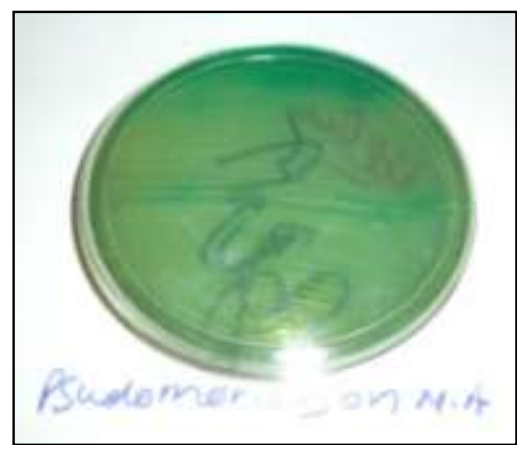

Fig.3 
Fig.4 Original colures of Hi media biochemical

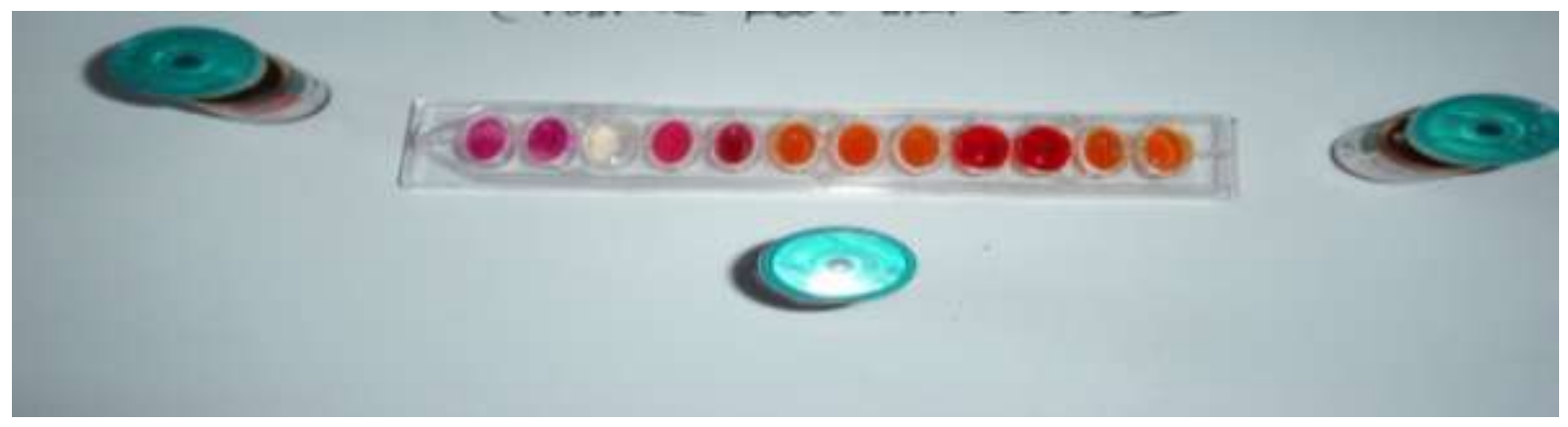

Fig.5 Change in colures of biochemical kit after test indicates positive for Staph. intermidus

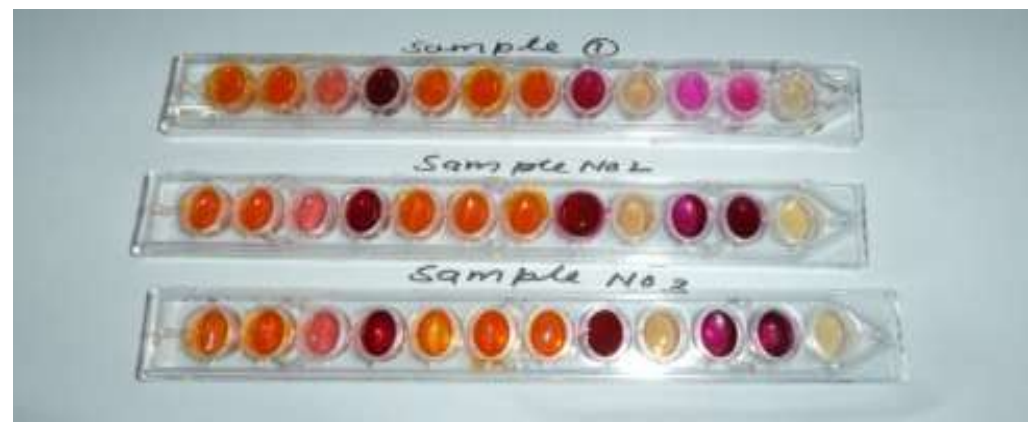

Fig.6 Antibiotics sensitivity test against Staphylococcus intermedius

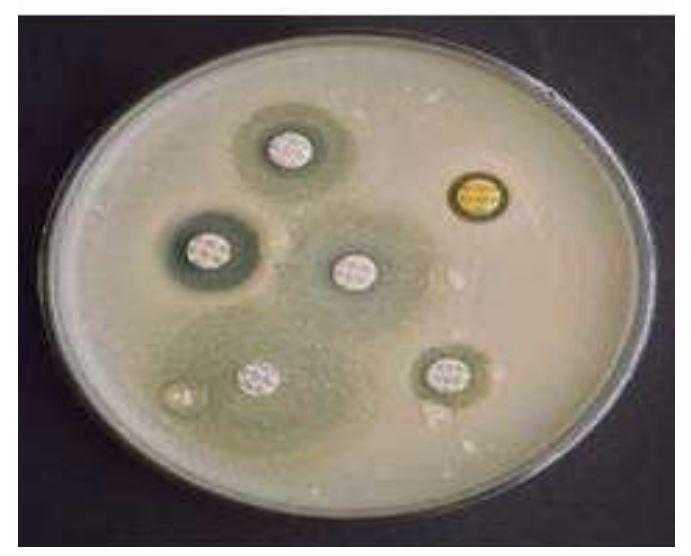

\section{In vitro- study}

All the 52 isolates of Staph intermedius exhibited susceptibility in descending orders; the highest susceptible and no resistance was shown to Amoxiciline -Clavulanic acid (100 percent) while Oxytetracycline was found 100 percent resistance followed by while Cephalexin (96.15 percent), Rifampicin (94 percent), Doxycycline (86 percent) and lowest 
susceptibility was recorded in Enrofloxacin (84.61 percent). An almost similar observation was found Shinizu et al., 2011 99\% resistance against Staphylococcus intermedius (Fig. 6 and Table 4).

Total 5 samples Coagulase-positive Staphylococcus aureus shown the resistance pattern of against same antibacterial drugs were reported as follows (0 \%), (20\%), (20),(40\%) (20\%), and Tetracycline was $(100 \%)$.While 2 samples of Coagulasenegative Staphylococci. Staphylococcus epidermidis exhibited almost 50 percent sensitivity too but it also reported to $100 \%$ resistances Tetracycline. Only one isolate was reported S. schleiferi sub spp. coagulans 100 percent Tetracycline was resistance compression to others.

It is concluded that in this study, the predominant skin microbes were identify as Staphylococcus spp. in dog .The pure culture of these bacteria showed maximum no of genus isolates were Staph. intermedius so it was considered as most common pathological organism in canine Pyoderma which showed maximum susceptibility against to Amoxiciline -Clavulanic acid (100 percent) followed by Cephalexin (96.15 percent), while Oxytetracycline was found 100 percent resistance.

\section{References}

Frank, L.A., Williamson, N.L., Wilkes, and R.P., Kania. 2002. The association of Staphylococcus schleiferi with canine pyodema. Veterinary Dermatology. 13:211-229.

Hart, C. A., and Kariuki, S. (1998). Antimicrobial resistance in developing countries. BMJ: British Medical Journal, 317(7159), 647.

Higgin,A.J. (1984). Diagnosis and treatment of sarcoptic mange in the Arabian camel. Wild. Anim. rev.49:2-5.

Hill, P.B., and Moriello, K.A. (1994).Canine pyoderma. J. Amer. Vet. Med. Assoc. 204: 334-340.

Hill, P.B., and Moriello, K.A. Canine pyoderma. J. Amer. Vet. Med. Assoc. 1994; 204: 334-340.

Hillier, A., Alcorn, J. R., Cole, L. K. 2006. Pyoderma caused by Pseudomonas aeruginosa infection in dogs: 20 cases. Veterinary Dermatology. 17: 432439.

Hoekstra, K. A., and Paulton, R. J. L. (2002). Clinical prevalence and antimicrobial susceptibility of Staphylococcus aureus and Staph. intermedius in dogs. Journal of applied microbiology. 93(3): 406-413.

Ihrke P. J. 2006. Bacterial infections of the skin. In: Greene CE (ed): Infectious Diseases of the Dog and Cat, Third Edition, Philadelphia, WB Saunders Co. 807-815.

Ihrke P.J., (2006). Bacterial infections of the skin. In: Greene CE (edn.): Infectious Diseases of the Dog and Cat, Third Edition, Philadelphia, WB Saunders Co. 807-815.

Jain, N.C. (1986). Schalms veterinary haematology 4th edn. Lea and Febiger Philadelphia.

Mark. (2003). Craig Diagnosis and management of pyoderma in the dog. In Practice. 25: 418-425.

May, E.R., Hnilica, K.A., and Frank, L.A. 2005.Isolation of Staphylococcus schleiferi from healthy dogs and dogs with otitis, pyoderma, or both. J. Am. Vet. Med. Assoc. 227(6):928-31.

Medleau, L., Long, R.E., Brown, J.,and Miller, W.H. (1986). Frequency and antimicrobial susceptibility of Staphylococcus species isolated from canine pyodermas. Am. J. Ve.t Res. 47(2):229-31. 
Morales CA, and Schultz KT, (1994). Antistaphylococcal antibodies in dogs with recurrent staphylococcal pyoderma. Vet Immunol Immunopathol. 42(2):137-47.

Papich, M.G. (1995). Antimicrobial Drugs. In: Ettinger S.B., Feildman E.C. (Ed). Textbook of Veterinary Internal Medicine- Disease of Dogs and Cats, W.B. Saunders, Philadelphia, 272284.

Paradis, M., Abbey, L., Baker, B, Coyne, M., Hannigan, M., Joffe, D., Pukay, B., Trettien, A., Waisglass, S, and Wellington, J. (2001). Evaluation of the clinical efficacy of marbofloxacin (Zeniquin $®)$ tablets for the treatment of canine pyoderma. Vet. Dermatol. 12: 163-169.

Patil, S.S., P. Madhava, Rao and N.A. Patil. (1999). Epidemiology and bacterial isolates in canine pyoderma. Indian J. Vet. Med. 19(1): 39-40.

Scott D.W. andMiller W. H. Small animal dermatology. Bacterial Skin Diseases. (Ed.Saunders) (2001); 274-335.

Scott, D. W., Miller, W. H., Griffin C. E. 1995. Muller and Kirk's Small Animal Dermatology, 5th edn. Philadelphia: W. B. Saunders Co. ix $-\mathrm{x}$.

Scott, D.W., Beningo, K.E., Miller, W.H. and Rothstein, E. (1998). Efficacy of clindamycin hydrochloride capsules for the treatment of deep pyoderma due to Staphylococcus intermedius infection in dogs. Canadian Vet. J. 39: 753-756.

Snedecor, G.W. and Cochran, W.G. (1994). Statistical Methods.8th edn. Lowa State univ. Press, Ames, lowa.

Vanni, M., Tognetti, R., Pretti, C., Crema, F., Soldani, G., Meucci, V., and Intorre, L. (2009). Antimicrobial susceptibility of Staphylococcus intermedius and Staphylococcus schleiferi isolated from dogs. Research in veterinary science, 87(2): 192-195.

\section{How to cite this article:}

Alok Kumar Chaudhary, Ashok Kumar and Mukesh shrivastva. 2019. Study on Prevalence and Resistance Patterns of Bacterial Pathogens Isolated from Canine Pyoderma. Int.J.Curr.Microbiol.App.Sci. 8(01): 2305-2311. doi: https://doi.org/10.20546/ijcmas.2019.801.241 